\title{
Significant Factors Causing Time Overrun in Construction Projects of Peninsular Malaysia
}

\author{
Aftab Hameed Memon ${ }^{1}$, Ismail Abdul Rahman ${ }^{1}$, Muhammad Akram ${ }^{1} \&$ Nornashima Md Ali ${ }^{1}$ \\ ${ }^{1}$ Faculty of Civil and Environmental Engineering, University Tun Hussein Onn Malaysia, Malaysia \\ Correspondence: Aftab Hameed Memon, Faculty of Civil and Environmental Engineering, University Tun \\ Hussein Onn Malaysia, Malaysia. Tel: 60-14-272-5620. E-mail: aftabm78@hotmail.com/aftabm78@gmail.com
}

Received: March 25, 2014

Accepted: April 22, $2014 \quad$ Online Published: June 25, 2014

doi:10.5539/mas.v8n4p16

URL: http://dx.doi.org/10.5539/mas.v8n4p16

\begin{abstract}
This study has identified the significant factors causing time overrun in Malaysian construction industry. Investigation through survey was carried out in central and southern parts of Malaysian among the respondents from three categories i.e. client, consultant and contractors. The feedback was received from 75 respondents against 300 companies contacted. The feedback was analyzed statistically which revealed that cash flow and financial difficulties faced by contractor, poor site management and supervision, incompetent subcontractor, shortage of workers and financial difficulties of the owner are major contributors of time overrun. The author recommends that the problem of time overrun can be controlled through proper planning of work, committed leadership and management, and effective communication system.
\end{abstract}

Keywords: time overrun, causative factors, Malaysian construction industry

\section{Introduction}

In this era of industrialization, Malaysian construction industry is key role player for economic and social development of the country (Ibrahim et al., 2010). But this industry is continuously facing severe concern of time overrun. It has become an essential need that effort be taken to lessen these overruns in time despite amplified uncertainties and complexities (Ribeiro, 1999). Currently, construction sector is considered as one of the riskiest, dynamic and challenging sector. This sector faced disaster between year 1997 and 2000 during the ASEAN economy crisis, but then is getting better gradually (Rahman et al., 2010). However, the schedule delay is a commonly faced criteria in the construction project due to poor risk management applications.

In Malaysian construction industry, time overrun is one of the critical problems faced in the construction project (Memon et al., 2011). Hamzah et al. (2011) mentioned that, time overrun often causes disorder in workflow and reduces of productivity. Consequently, projects are completed beyond the contract time which can result in budget overrun, contractual claims or also abandonment of the projects (Abedi et al., 2011a). As reported by Utusan Malaysia on $2^{\text {nd }}$ Jun 2009, 80\% of Public Works Department known as Jaban Kerja Raya (JKR) projects in year 2008 were delayed, and the government had to bear the increased cost as well as waste of time and energy (Embong, 2011). Various practices have been adopted by the government to overcome this problem such as involving the private sector in government developments, hiring of experience project managers so that the projects can be managed effectively for achieving completion of time. However, the time performance of construction projects is still poor (Embong, 2011). This problem of time overrun is caused by various factors, and in order to control this problem, it is very essential to adopt effective management actions especially to control the factors causing time overruns (Sambasivan \& Soon, 2007). Hence, this study focused on identifying the significant time overrun factors. The limitations of this study include that the data sampling was done in central (Wilayah Persekutuan, Selangor and Negeri Sembilan States) and southern part (Johor and Melaka states) of Peninsular Malaysia.

\section{Related Works}

Construction is a vast industry which provides various projects for residential, industrial or commercial facilities (William, 2010). Hence, huge sum of money are expended for providing new facilities or retrofitting existing facilities to satisfy the needs of society for shelter and economic growth. Construction industry is an essential sector for any country as it provides necessary requirement for improving the standard of life (Abedi et al. 
2011b). Similarly, like other countries of the world, construction is a basic industry considered in Malaysian development. Development of construction industry in Malaysia has been boosted up right from the time of independence (Ibrahim et al., 2010). It is important in propelling the Malaysia economy. Thus, it is very critical to achieve successful projects. One of the major factors for project success is timely completion of the project. Unfortunately, this sector faces a major problem of late completion of the projects. There are various factors that cause construction time overrun. Since this matter has become crucial in the construction industry, a comprehensive literature review was conducted to gather causes of time overrun. Mahamid (2011) mentioned that major factors of time overrun are poor communication between parties, resource management and delay in commencement. Abedi et al. (2011b) identified 17 factors of time overrun among which insufficient funds of clients, improper project feasibility, and lack of capable representative, inappropriate construction methods, inadequate contractor experience and incompetent project team were regarded as major factors. Fugar and Agyakwah-Baah (2010) reported that top ten factors affecting time overrun in Ghana are delay in honoring certificates, underestimation of the cost of project, underestimation of complexity of project, difficulty in accessing bank credit, poor supervision, underestimation of time for completion of projects by contractors, shortage of materials, poor professional management, fluctuation of prices/rising cost of materials and poor site management

Ramabathan et al. (2011) stated that high demand on the resources such as labour, material and equipment may cause scarce, and this will hamper to the project execution. If this situation prolonged and left unchecked, it may affecting the project progress. They also concluded that mismanagement of the project by contractor, consultant and owner will lead to time overrun. From seven case studies, the risk factor causing time overrun were found as shortage and lack in quality materials and appropriate equipments in the local market, no material delivery schedule prepared by the contractor; delay in materials, drawing and proposal approvals by consultant; Bad weather conditions; fluctuation in raw material prices and fossil fuels; delay in dealing with land and property acquisition causing delay to construction work; the distance between each project site posed challenges in logistic planning to distribute the resources; and reworks due to poor quality work standards. For eliminating the negative impact of these factors, these problems should be addressed at pre-design stage so that the negative impact of these factors can be eliminated. For identification of common factors of time overrun, a comprehensive literature review was carried out which resulted in identifying a total of 30 factors categorized into five groups as owner/client responsibility (OWN), consultant responsibility (COS), contractor responsibility $(\mathrm{CON})$, resource related factors (RES) an others $(\mathrm{OTH})$ as shown in Table 1.

Table 1. Mapping factors causing time overrun

\begin{tabular}{|c|c|c|}
\hline Category & Factors & References \\
\hline \multirow[t]{6}{*}{$\begin{array}{l}\text { Owner/client } \\
\text { Responsibility } \\
\text { (OWN) }\end{array}$} & OWN01: Change in the scope of the project & $\begin{array}{l}\text { Mahamid (2011), Abedi et al. (2011a), } \\
\text { Hamzah et al. (2011), Fugar \& Agyakwah- } \\
\text { Baah (2010), Yang \& Wei (2010) }\end{array}$ \\
\hline & $\begin{array}{l}\text { OWN02: Delay in progress payment by } \\
\text { owner }\end{array}$ & $\begin{array}{l}\text { Smbasivan \& Soon (2007), Alaghbari et al., } \\
\text { (2007), Enshassi et al. (2009), Le-Hoai et al. } \\
\text { (2008), Mahamid (2011), Abedi et al. } \\
\text { (2011a), Hamzah et al. (2011), Fugar \& } \\
\text { Agyakwah-Baah (2010) }\end{array}$ \\
\hline & OWN03: Financial difficulties of owner & $\begin{array}{l}\text { Mahamid (2011), Hamzah et al. (2011), } \\
\text { Fugar \& Agyakwah-Baah (2010), Le-Hoai et } \\
\text { al. (2008), Yang \& Wei (2010), Smbasivan \& } \\
\text { Soon (2007), Alaghbari et al., (2007), }\end{array}$ \\
\hline & OWN04: Delays in decisions making & $\begin{array}{l}\text { Mahamid (2011), Abedi et al. (2011a), } \\
\text { Hamzah et al. (2011), Yang \& Wei (2010), } \\
\text { Smbasivan \& Soon (2007), Alaghbari et al., } \\
\text { (2007), }\end{array}$ \\
\hline & OWN05: Owner interference & $\begin{array}{l}\text { Abedi et al. (2011a), Smbasivan \& Soon } \\
\text { (2007), Enshassi et al. (2009) }\end{array}$ \\
\hline & $\begin{array}{l}\text { OWN06: Unrealistic contract duration and } \\
\text { requirements imposed }\end{array}$ & $\begin{array}{l}\text { Mahamid (2011), Smbasivan \& Soon (2007), } \\
\text { Yang \& Wei (2010) }\end{array}$ \\
\hline
\end{tabular}




\begin{tabular}{|c|c|c|}
\hline Category & Factors & References \\
\hline \multirow[t]{6}{*}{$\begin{array}{l}\text { Consultant } \\
\text { Responsibility } \\
\text { (COS) }\end{array}$} & $\begin{array}{l}\text { COS01: Delay in inspection and approval of } \\
\text { completed works }\end{array}$ & $\begin{array}{l}\text { Mahamid (2011), Hamzah et al. (2011), } \\
\text { Fugar \& Agyakwah-Baah (2010), Smbasivan } \\
\text { \& Soon (2007), Alaghbari et al., (2007), } \\
\text { Enshassi et al. (2009), Le-Hoai et al. (2008), }\end{array}$ \\
\hline & $\begin{array}{l}\text { COS02: Unrealistic contract duration and } \\
\text { requirements imposed }\end{array}$ & $\begin{array}{l}\text { Mahamid (2011), Smbasivan \& Soon (2007), } \\
\text { Yang \& Wei (2010) }\end{array}$ \\
\hline & COS03: Frequent design changes & $\begin{array}{l}\text { Mahamid (2011), Smbasivan \& Soon (2007), } \\
\text { Le-Hoai et al. (2008), }\end{array}$ \\
\hline & COS04: Mistakes and Errors in design & $\begin{array}{l}\text { Mahamid (2011), Fugar \& Agyakwah-Baah } \\
\text { (2010), Enshassi et al. (2009), Le-Hoai et al. } \\
\text { (2008), Yang \& Wei (2010) }\end{array}$ \\
\hline & $\begin{array}{l}\text { COS05: Delay Preparation and approval of } \\
\text { drawings }\end{array}$ & $\begin{array}{l}\text { Mahamid (2011), Hamzah et al. (2011), } \\
\text { Smbasivan \& Soon (2007), Alaghbari et al., } \\
\text { (2007), Enshassi et al. (2009) }\end{array}$ \\
\hline & $\begin{array}{l}\text { COS06: Incomplete design at the time of } \\
\text { tender }\end{array}$ & $\begin{array}{l}\text { Mahamid (2011), Alaghbari et al., (2007), } \\
\text { Yang \& Wei (2010) }\end{array}$ \\
\hline \multirow[t]{6}{*}{$\begin{array}{l}\text { contractor } \\
\text { responsibility } \\
\quad(\mathrm{CON})\end{array}$} & CON01: Inadequate planning and scheduling & $\begin{array}{l}\text { Mahamid (2011), Abedi et al. (2011a), } \\
\text { Hamzah et al. (2011), Fugar \& Agyakwah- } \\
\text { Baah (2010), Smbasivan \& Soon (2007), } \\
\text { Yang \& Wei (2010) }\end{array}$ \\
\hline & CON02: Lack of experience & $\begin{array}{l}\text { Abedi et al. (2011a), Hamzah et al. (2011), } \\
\text { Fugar \& Agyakwah-Baah (2010), Smbasivan } \\
\text { \& Soon (2007), Alaghbari et al., (2007), } \\
\text { Enshassi et al. (2009) }\end{array}$ \\
\hline & $\begin{array}{l}\text { CON03: Poor site management and } \\
\text { supervision }\end{array}$ & $\begin{array}{l}\text { Mahamid (2011), Abedi et al. (2011a), } \\
\text { Hamzah et al. (2011), Fugar \& Agyakwah- } \\
\text { Baah (2010), Smbasivan \& Soon (2007), } \\
\text { Alaghbari et al., (2007), Enshassi et al. } \\
\text { (2009), Le-Hoai et al. (2008), }\end{array}$ \\
\hline & CON04: Incompetent subcontractors & $\begin{array}{l}\text { Abedi et al. (2011a), Hamzah et al. (2011), } \\
\text { Fugar \& Agyakwah-Baah (2010), Smbasivan } \\
\text { \& Soon (2007), Alaghbari et al., (2007), } \\
\text { Le-Hoai et al. (2008), }\end{array}$ \\
\hline & $\begin{array}{l}\text { CON05: Cash flow and financial difficulties } \\
\text { faced by contractors }\end{array}$ & $\begin{array}{l}\text { Mahamid (2011), Abedi et al. (2011a), } \\
\text { Hamzah et al. (2011), Alaghbari et al., (2007) }\end{array}$ \\
\hline & CON06: Mistakes during construction & $\begin{array}{l}\text { Mahamid (2011), Hamzah et al. (2011), } \\
\text { Smbasivan \& Soon (2007), Alaghbari et al., } \\
\text { (2007), Enshassi et al. (2009), }\end{array}$ \\
\hline \multirow{4}{*}{$\begin{array}{c}\text { Resource } \\
\text { Related } \\
\text { Factors (RES) }\end{array}$} & RES01: Fluctuation of prices of materials & Mahamid (2011), Le-Hoai et al. (2008), \\
\hline & RES02: Shortages of materials & $\begin{array}{l}\text { Mahamid (2011), Fugar \& Agyakwah-Baah } \\
\text { (2010), Smbasivan \& Soon (2007), Alaghbari } \\
\text { et al., (2007), Enshassi et al. (2009), Le-Hoai } \\
\text { et al. (2008), }\end{array}$ \\
\hline & $\begin{array}{l}\text { RES03: Late delivery of materials and } \\
\text { equipment }\end{array}$ & $\begin{array}{l}\text { Hamzah et al. (2011), Fugar \& Agyakwah- } \\
\text { Baah (2010), Alaghbari et al., (2007), } \\
\text { Enshassi et al. (2009) }\end{array}$ \\
\hline & RES04: Insufficient Numbers of equipment & $\begin{array}{l}\text { Hamzah et al. (2011), Smbasivan \& Soon } \\
\text { (2007), Alaghbari et al., (2007), Enshassi et } \\
\text { al. (2009) }\end{array}$ \\
\hline
\end{tabular}




\begin{tabular}{ccl}
\hline Category & \multicolumn{1}{c}{ Factors } & References \\
\hline Resource & RES05: labor productivity & Hamzah et al. (2011), Smbasivan \& Soon \\
Related & & (2007), Alaghbari et al., (2007), Enshassi et \\
Factors (RES) & & al. (2009) \\
& \multirow{2}{*}{ RES06: Shortage of site workers } & Mahamid (2011), Abedi et al. (2011a), \\
& & Hamzah et al. (2011), Fugar \& Agyakwah- \\
& & Baah (2010), Alaghbari et al., (2007), \\
& Enshassi et al. (2009), Le-Hoai et al. (2008)
\end{tabular}

Others (OTH) OTH01: Effect of weather

OTH02: Unforeseen ground condition

OTH03: Accidents on site

OTH04: Lack of coordination between parties

OTH05: Lack of communication between parties

OTH06: Laws and Regulatory Framework
Mahamid (2011), Hamzah et al. (2011), Fugar \& Agyakwah-Baah (2010), Smbasivan $\&$ Soon (2007), Enshassi et al. (2009), Le-Hoai et al. (2008), Yang \& Wei (2010)

Mahamid (2011), Fugar \& Agyakwah-Baah (2010), Smbasivan \& Soon (2007), Enshassi et al. (2009), Le-Hoai et al. (2008), Yang \& Wei (2010)

Fugar \& Agyakwah-Baah (2010), Enshassi et al. (2009)

Hamzah et al. (2011), Alaghbari et al., (2007)

Mahamid (2011), Abedi et al. (2011a), Hamzah et al. (2011), Fugar \& AgyakwahBaah (2010), Smbasivan \& Soon (2007), Enshassi et al. (2009), Le-Hoai et al. (2008),

Fugar \& Agyakwah-Baah (2010), Enshassi et al. (2009), Le-Hoai et al. (2008), Yang \& Wei (2010)

\section{Research Method}

Research method refers to a systematic stepwise process to carry out any research work. This study was conducted through several phases that include the literature review, data collection and discussion, and conclusion. Through literature review, the identified 30 common factors of time overrun were investigated for determining significance level in causing time overrun in Malaysian construction industry. Data collection was carried out through structural questionnaire survey amongst the practitioner involved in handling construction project in central and southern regions of peninsular Malaysia. The questionnaires were distributed by post, email and in person among targeted respondents i.e. client (Public Works Department); consultants and contractors registered in top groups i.e. Grade 6 and Grade 7 with Construction Industry Development Board (CIDB) Malaysia. Assessment of causes of time overrun was carried out using 5-point likert scale from 1 to 5 representing not significant, slightly significant, moderately significant, very significant and extremely significant respectively. Data analysis was done calculating frequency and Relative Importance Index (RII). Frequency calculation was performed with software SPSS v17 while Relative Importance Index (RII) was calculated with following formula, adopted from (Memon et al. 2012) as RII is the suitable method to do the ranking analysis (Doloi et al. 2012).

$$
R I I=\frac{\sum_{i=1}^{5} w x}{A \times N}
$$

Where; RII = Relative Importance Index

$\mathrm{w} \quad=$ weighting given to each factor by respondents and it ranges from 1 to 5

$\mathrm{x}=$ frequency of it response given for each factor

A $=$ highest weight (i.e. 5 in this case)

$\mathrm{N}=$ total number of participants

From RII results, the ranking for different factors was determined to discover the significant factors causing time overrun in construction projects. 


\section{Data Analysis and Discussion on Findings}

A total of three hundred (300) sets of questionnaires were sent to various construction companies (clients, consultants and contractors) located in central and southern parts of Peninsular Malaysia. Only, seventy-five (75) completed sets were received back which were evaluated with SPSS and Microsoft Excel program in order to determine the important factors that causing construction time overrun. Following sections discuss finding of the survey.

\subsection{Demographics of Respondents}

Demography of the respondents was assessed to see the factual data of respondents involved in the data collection. These respondents represented three categories of the personnel with $31 \%$ ( 23 respondents) from client category, 27\% (20 respondents) from consultant category and $42 \%$ (32 respondents) from contractor category. These findings are presented in Figure 1.

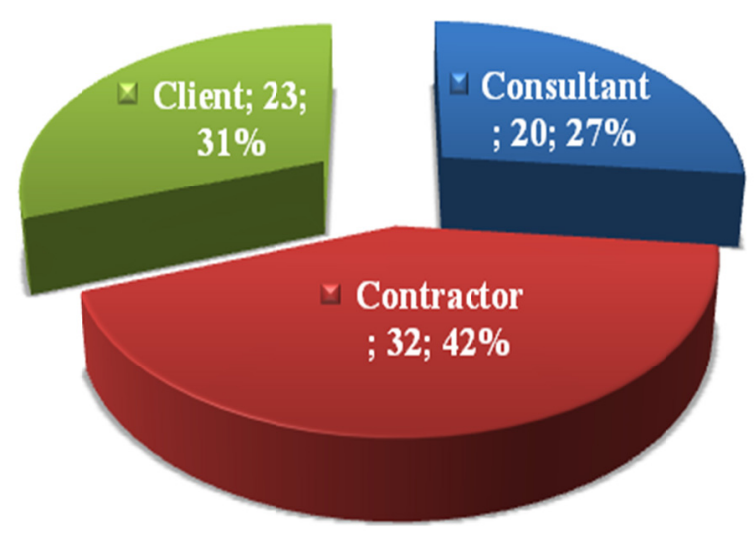

Figure 1. Type of organizations of respondents

Amongst, 69\% respondents' represented private organization while remaining $31 \%$ respondents is engaged in government organizations. The participants have experience of handling various types of projects as summarized in Figure 2.

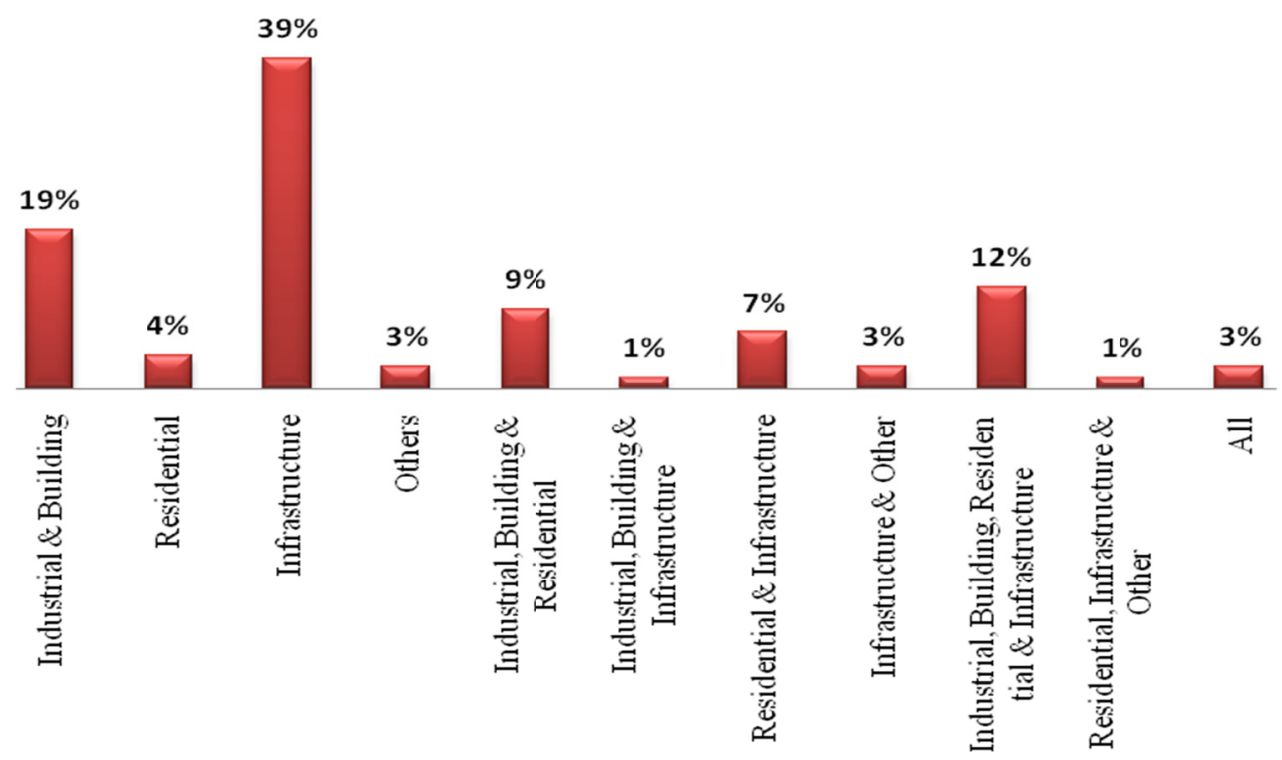

Figure 2. Type of projects handled by respondents

From Figure 2, it can be seen that infrastructures are the highest field of work with $39 \%$ followed by industrial and building projects with $19 \%$ and others field of work with a relatively equal values. Further, majority of 
respondents' participating in the survey had experience of handling large projects i.e. projects with a contract amount more than RM 5 Million (Memon et al. 2013). The results are presented in Figure 3.

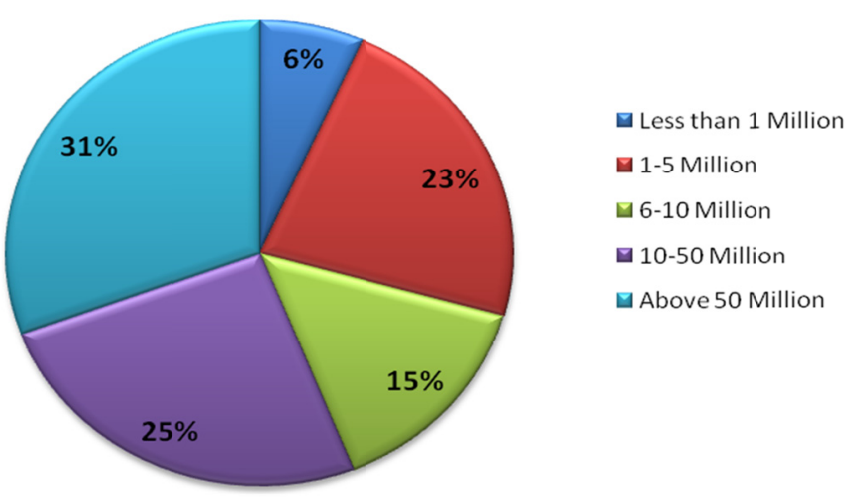

Figure 3. Size of projects handled by the respondents

Figure 3 shows that, $31 \%$ of respondents were involved in handling projects above 50 million; $25 \%$ of respondents were involved in handling projects of 10-15 million; $23 \%$ of respondents were involved in handling projects of 1-5 million; $14 \%$ of respondents were involved in handling projects of $6-10$ million and $7 \%$ of respondents were involved in handling projects of less than 1 million. All the respondents have attained various level of academic qualification as shown in Figure 4.

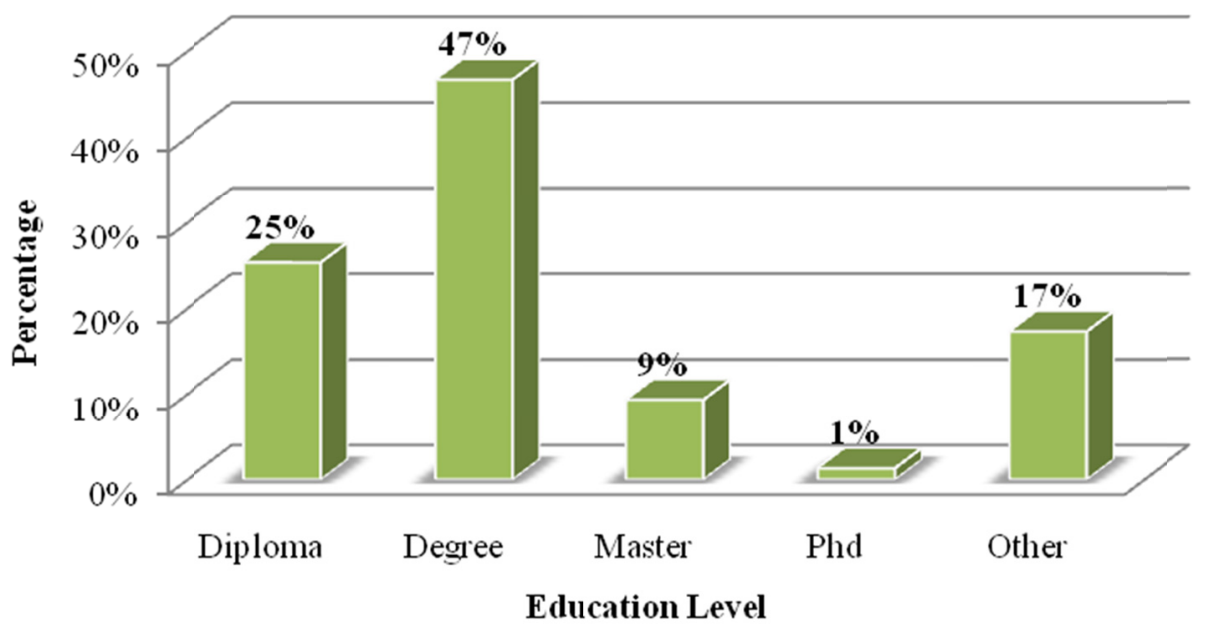

Figure 4. Academic qualifications of the respondents

From Figure 4, it can be seen that most of the respondents involved in the survey were holding bachelor degree in term of educational qualification with the highest percentage $47 \%$. $25 \%$ of respondent were diploma holders; master holders were $9 \%$ of respondents and $\mathrm{PhD}$ holders $1 \%$. While $17 \%$ of respondents consist of certificates such as engineering certificate, STPM (High Certificate of Malaysian Education), SPM (Certificate of Malaysian Education). Table 2 shows the summary of respondents working position in the category. 
Table 2. Respondents' Working Position in the Organization

\begin{tabular}{lccc}
\hline POSITION & Frequency & Percent & Cumulative Percent \\
\hline Project Manager & 8 & 10.7 & 10.7 \\
Director & 7 & 9.3 & 20.0 \\
Engineer & 19 & 25.3 & 45.3 \\
Assistant Engineers & 11 & 14.7 & 60.0 \\
Site Supervisors & 15 & 20.0 & 80.0 \\
Quantity Surveyor & 13 & 17.3 & 97.3 \\
Technician & 2 & 2.7 & 100.0 \\
Total & 75 & 100.0 & \\
\hline
\end{tabular}

Results show that mainly three types of position were held by most respondents including $19(25.3 \%)$ engineers, 8 project managers with $10.7 \%, 7$ directors with $9.3 \%$ and the rest were others. Besides these, other respondents included assistant engineers, site supervisors, technician and quantity surveyor. The respondents involved in the survey had several years of experience of handling construction projects. Survey statistics showed that $54 \%$ of the respondents have experience below 10 years, $31 \%$ of respondents with 11 to 20 years experience, $12 \%$ with 21 to 30 years of experience and only $3 \%$ of respondents with above 31 years experience. The results are presented in Figure 5.

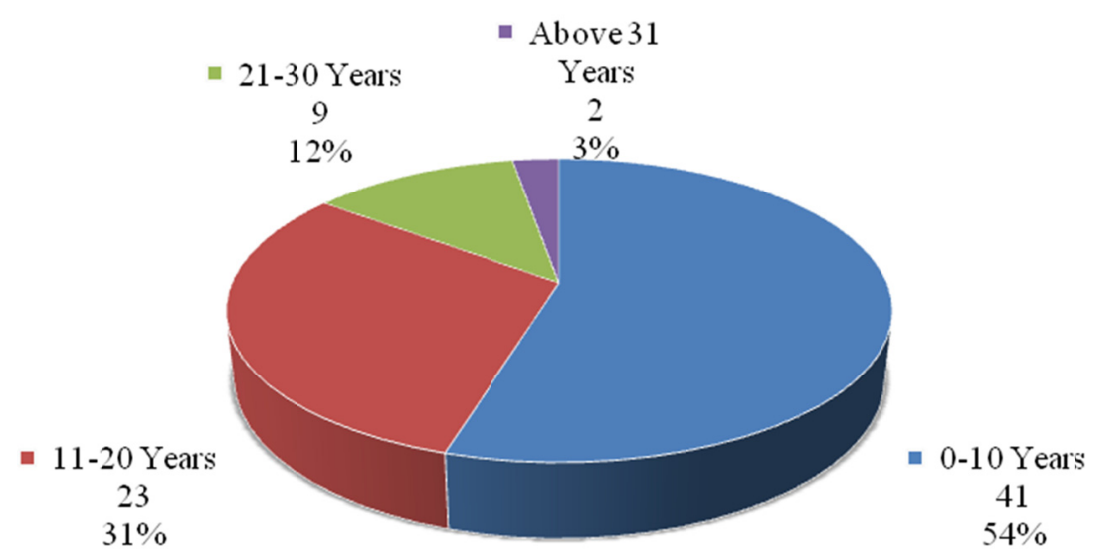

Figure 5. Working Experience of the Respondents

\subsection{Reliability Test for Factors Causing Time Overrun}

Prior to ranking of factors causing time overrun, reliability test was carried out to ensure that the data collected are valid and reliable for further analysis (Memon et al., 2011b). Reliability means consistency where for this analysis; the reliability test was done for the factors causing construction time overrun. As stated by Yang et al. (2010), the reliability test can prove the factors stated are relevant and can be used for the next analysis. Reliability test was carried out by evaluating Cronbach $\alpha$ obtained through statistical software package SPSS. Reliability test was done for every group of data in factors causing construction time overrun. Results of reliability test are presented in table 3 , where it can be seen that the values are in the range of 0.827 to 0.952 . These values considered high as compared to cut-off value i.e. 0.7 (Yang et al. 2010) which shows that the reliability of the questionnaire is assured, and questionnaire data are valid and reliable. 
Table 3. Reliability test results

\begin{tabular}{lc}
\hline Group of Data & Cronbach $\boldsymbol{\alpha}$ \\
\hline Overall & 0.952 \\
Owner Responsibility & 0.845 \\
Consultant Responsibility & 0.868 \\
Contractor Responsibility & 0.907 \\
Resource Related Factor & 0.827 \\
Others & 0.872 \\
\hline
\end{tabular}

\subsection{Ranking for Factors Causing Construction Time Overrun}

Significance of major contributing factors causing construction time overrun was identified in the survey. Respondents were asked to rank the factors with 5-likert scale as:

1- Not significant

2- Slightly significant

3- Moderately significant

4- Very significant

5- Extremely significant

Data were analyzed by using RII; the factors were ranked by group of contractor, consultant, client and overall view. Discussion is enclosed for each group to derive comprehensive results for each factor.

\subsubsection{Owner Responsibility (OWN)}

Table 4 shows the factor causing construction time overrun in owner responsibility category. The ranking was divided into three groups of respondents which are client, consultant and contractor.

Table 4. Ranking of factors related to owner responsibility

\begin{tabular}{llcccccc}
\hline \multirow{2}{*}{ Factor } & \multirow{2}{*}{ Description } & \multicolumn{2}{c}{ Client } & \multicolumn{3}{c}{ Consultant } & \multicolumn{2}{c}{ Contractor } \\
\cline { 3 - 7 } & & RII & Rank & RII & Rank & RII & Rank \\
\hline OWN 03 & Financial difficulties of owner & 0.64 & 1 & 0.65 & 3 & 0.79 & 1 \\
OWN 06 & Unrealistic contract duration and & 0.63 & 2 & 0.54 & 6 & 0.67 & 5 \\
& requirements imposed & & & & & & \\
OWN 05 & Owner interference & 0.62 & 3 & 0.55 & 5 & 0.63 & 6 \\
OWN 02 & Delay in progress payment by owner & 0.59 & 4 & 0.73 & 1 & 0.73 & 3 \\
OWN 04 & Delays in decisions making & 0.59 & 5 & 0.65 & 4 & 0.72 & 4 \\
OWN 01 & Change in the scope of the project & 0.56 & 6 & 0.68 & 2 & 0.75 & 2 \\
\hline
\end{tabular}

According to client respondents, financial difficulties of owner is the most significant cause of time overrun and is placed at first rank with RII value of 0.64 . This factor may cause time overrun to a construction project because when client have issue in financial problem, payment to contractor will be pending. As stated by Rahman et al. (2011), problems in payment at the higher end of the hierarchy will lead to a serious knock-on cash flow problem down the chain of contracts which affects the construction progress. Second ranked factor as perceived from client is unrealistic contract duration and requirement imposed with RII 0.63 . This is followed by owner interference in the construction project with RII 0.62.

From consultant's view, the respondents agreed that the delay in progress payment by owner placed at first rank with RII 0.73. Delay in payment is defined as failure of a paymaster to pay within the period of honoring of certificates as provided in the contract (Rahman et al., 2011). This factor also can be related with financial difficulty by owner which is the third ranked factor with RII value of 0.65 by consultant's view. This factor can lead to delay in payment and thus causing construction time overrun. Second ranked factor with RII 0.68 as indicated by consultant group is change in the scope of the project.

From contractor's view, the respondents agreed with the client that financial difficulties of owner is the first 
ranked factor with RII 0.79. Second ranked factor as perceived by the contractor group is agreed with the consultant as change in the scope of the project. For the third rank with RII 0.73 , the respondents from contractor group placed delay in progress payment by owner.

In essence, the financial problem by owner is a major factor in owner related category in causing construction times overrun. This is because most of the contractors use monthly payment to roll their fund to continue the construction. When the payment is delayed by client or owner, it can affect the schedule of the project.

\subsubsection{Consultant Responsibility (COS)}

Table 5 shows the results for consultant responsibility from the perspective of the client, consultant and contractor.

Table 5. Ranking of factors related to consultant responsibility

\begin{tabular}{llcccccc}
\hline \multirow{2}{*}{ Factor } & Description & \multicolumn{2}{c}{ Client } & \multicolumn{2}{c}{ Consultant } & \multicolumn{2}{c}{ Contractor } \\
\cline { 3 - 7 } & & RII & Rank & RII & Rank & RII & Rank \\
\hline COS 06 & Incomplete design at the time of tender & 0.70 & 1 & 0.62 & 3 & 0.69 & 4 \\
COS 02 & Poor project Management & 0.70 & 2 & 0.54 & 6 & 0.68 & 5 \\
COS 05 & Delay Preparation and approval of drawings & 0.64 & 3 & 0.62 & 2 & 0.74 & 2 \\
COS 03 & Frequent design changes & 0.61 & 4 & 0.70 & 1 & 0.76 & 1 \\
COS 04 & Mistakes and Errors in design & 0.57 & 5 & 0.58 & 4 & 0.72 & 3 \\
COS 01 & $\begin{array}{l}\text { Delay in inspection and approval of } \\
\text { completed works }\end{array}$ & 0.56 & 6 & 0.57 & 5 & 0.63 & 6 \\
\hline
\end{tabular}

From client perspective, the respondents agreed that incomplete design at the time of tender is the most significant factors and is placed at first rank with RII 0.70 . Unrealistic contract duration and requirements imposed with the same RII value is also very significant factors. This is followed by delay preparation and approval of drawing with RII 0.64. From client's viewpoint, the three factors listed are the very significant factors causing construction time overrun for consultant responsibility category.

Frequent design change is ranked as the most significant factor by consultants and contractors group of respondents with RII 0.70 and 0.76 respectively. Delay preparation and approval of drawing is the second major factor as agreed by the consultant and contractor with RII 0.62 and 0.74 respectively. For third major factor, the consultant group placed incomplete design at the time of tender with RII 0.62. While for the contractor group of respondents argue that mistakes and errors in design ( $\mathrm{RII}=0.72)$ are $3^{\text {rd }}$ major factor in causing time overrun. In essence, the most significant factor in consultant responsibility group of factors is frequent design changes.

\subsubsection{Contractor Responsibility (CON)}

Table 6 shows the relative importance index results of factors related to contractor responsibility causing time overrun

Table 6. Ranking of factors related to contractor responsibility

\begin{tabular}{llcccccc}
\hline \multirow{2}{*}{ Factor } & \multirow{2}{*}{ Description } & \multicolumn{2}{c}{ Client } & \multicolumn{2}{c}{ Consultant } & \multicolumn{2}{c}{ Contractor } \\
\cline { 3 - 7 } & & RII & Rank & RII & Rank & RII & Rank \\
\hline CON 01 & Inadequate planning and scheduling & 0.71 & 1 & 0.61 & 5 & 0.67 & 5 \\
CON 02 & Lack of experience & 0.67 & 2 & 0.59 & 6 & 0.67 & 6 \\
CON 03 & Poor site management and supervision & 0.67 & 3 & 0.70 & 2 & 0.74 & 3 \\
CON 04 & Incompetent subcontractors & 0.67 & 4 & 0.69 & 3 & 0.75 & 2 \\
CON 05 & Cash flow and financial difficulties faced by & 0.66 & 5 & 0.71 & 1 & 0.79 & 1 \\
& contractors & & & & & & \\
CON 06 & Mistakes during construction & & & & & & \\
\hline
\end{tabular}

From Table 6, it can be seen that client representatives agreed that inadequate planning and scheduling is the most significant factor causing construction time overrun for contractor responsibility category with the RII 0.71 . However, it is differing for consultants and contractor group of respondent where they have mentioned cash flow and financial difficulties faced by contractor is the most significant factor than other factors with RII value 0.71 
and 0.79 respectively.

This shows that the financial problem is also the main factor for contractor responsibility in causing construction time overruns. The financial should not be a problem for the contractors if they have proper financial management. However, most of the contractors have more than one projects at one time; therefore they have difficulties in financing and managing the projects. They often switch the money from one project to another and vice-versa, and when it ran out of money, the projects are slowed down and sometimes completely stopped.

For second and third rank, the factors listed by client are lack of experience (RII=0.67) and poor site management and supervision (RII=0.67). Consultants group of respondent placed poor site management and supervision (RII $=0.70)$ at second rank, and incompetent subcontractors $(\mathrm{RII}=0.69)$ at third rank. While, contractors group of respondents placed incompetent subcontractors at second rank with RII 0.75 and poor site management and supervision at third rank with RII 0.74 .

\subsubsection{Resource Related Factors (RES)}

There are six factors listed in the resource related factors causing construction time overrun and results are presented in Table 7.

Table 7. Ranking of factors related to resource related factors

\begin{tabular}{llcccccc}
\hline \multirow{2}{*}{ Factor } & \multirow{2}{*}{ Description } & \multicolumn{2}{c}{ Client } & \multicolumn{2}{c}{ Consultant } & \multicolumn{2}{c}{ Contractor } \\
\cline { 3 - 8 } & & RII & Rank & RII & Rank & RII & Rank \\
\hline RES 06 & Shortage of site workers & 0.70 & 1 & 0.68 & 4 & 0.74 & 1 \\
RES 05 & labor productivity & 0.67 & 2 & 0.64 & 5 & 0.68 & 4 \\
RES 02 & Shortages of materials & 0.66 & 3 & 0.69 & 2 & 0.73 & 2 \\
RES 01 & Fluctuation of prices of materials & 0.65 & 4 & 0.73 & 1 & 0.64 & 5 \\
RES 04 & Insufficient Numbers of equipment & 0.64 & 5 & 0.62 & 6 & 0.64 & 6 \\
RES 03 & Late delivery of materials and equipment & 0.63 & 6 & 0.69 & 3 & 0.70 & 3 \\
\hline
\end{tabular}

Table 7 shows that the respondents from clients representative and contractors representative agreed that the shortage of site workers is the most significant factor contributes to the time overrun in construction project $\mathrm{RII}=0.70$ with $\mathrm{RII}=0.74$ respectively. The shortage of site worker will slow down the project progress due to low productivity of site activity. The labor productivity is measured as ratio of output per labor-hour, so if the low quality of labor is being occupied, it might affect the project schedule and cause the construction time overrun (Wei, 2010). On the other hand, consultant group of respondents' ranked fluctuation of prices of materials as the most significant factor causing construction time overrun with RII value 0.73 . At the second rank, consultant group and contractor group of respondents agreed that the shortage of material can cause construction time overrun with RII value 0.69 and 0.73 respectively. Late delivery of materials and equipment is placed at third rank for factors causing time overrun in construction by consultants $(\mathrm{RII}=0.69)$ and contractors $(\mathrm{RII}=0.70)$ group of respondent. While, client group of respondent placed labor productivity at second rank $(\mathrm{RII}=0.67)$ and for the third rank they placed shortage of materials with $\mathrm{RII}=0.66$.

4.3.5 Other Factors (OTH)

Table 8 shows the result for factors listed in category "other factors".

Table 8. Ranking of factors related to other factors

\begin{tabular}{llcccccc}
\hline \multirow{2}{*}{ Factor } & \multicolumn{1}{c}{ Description } & \multicolumn{2}{c}{ Client } & \multicolumn{2}{c}{ Consultant } & \multicolumn{2}{c}{ Contractor } \\
\cline { 3 - 8 } & & RII & Rank & RII & Rank & RII & Rank \\
\hline OTH 01 & Effect of weather & 0.64 & 1 & 0.73 & 1 & 0.64 & 3 \\
OTH 02 & Unforeseen ground condition & 0.63 & 2 & 0.71 & 2 & 0.70 & 1 \\
OTH 04 & Lack of coordination between parties & 0.58 & 3 & 0.69 & 4 & 0.64 & 4 \\
OTH 06 & Laws and Regulatory Framework & 0.57 & 4 & 0.61 & 5 & 0.59 & 5 \\
OTH 05 & Lack of communication between parties & 0.57 & 5 & 0.70 & 3 & 0.65 & 2 \\
OTH 03 & Accidents on site & 0.53 & 6 & 0.52 & 6 & 0.53 & 6 \\
\hline
\end{tabular}

From table 8 , effect of weather is listed as the first rank by client $\mathrm{RII}=0.64$ is agreed by consultants with 
RII $=0.73$. Contractor group of respondents has chosen unforeseen ground condition as the first rank with RII 0.70. This is the main factor because, in bad weather, some type of works cannot be executed. For example: in raining day, the concrete work cannot be done because it can cause the increased water content in the mixture of concrete increases and can reduce the quality of the concrete. So the work will be postponed, and it can contribute to construction time overrun. The weather cannot predict accurately, so in this situation it can be considered as the non-compensable delay.

Second ranked factor as stated by client and consultant is unforeseen ground condition with RII value 0.63 and 0.71 respectively. While contractor group with RII value of 0.65 listed lack of communication between parties at second rank. Client group of respondents agreed that the lack of coordination between parties can cause construction time overrun and listed as third ranked factor with RII 0.58. Consultant group has chosen lack of communication between parties at third rank with RII value 0.70 and contractor group stated effect of weather at the third rank with RII value 0.64 .

\subsubsection{Overall Ranking}

Based on the overall data, the combined perception of all the respondents on all the thirty factors causing construction time overrun was analyzed and ranked as shown in Table 9.

Table 9. Rank analysis of factors for overall data

\begin{tabular}{lccc}
\hline \multicolumn{1}{c}{ Description } & RII & Rank & Category \\
\hline Cash flow and financial difficulties faced by contractors & 0.73 & 1 & Contractor \\
Poor site management and supervision & 0.71 & 2 & Contractor \\
Incompetent subcontractors & 0.71 & 3 & Contractor \\
Shortage of site workers & 0.71 & 4 & Resource \\
Financial difficulties of owner & 0.71 & 5 & Owner \\
Frequent design changes & 0.70 & 6 & Consultant \\
Shortages of materials & 0.70 & 7 & Resource \\
Delay in progress payment by owner & 0.69 & 8 & Owner \\
Unforeseen ground condition & 0.68 & 9 & Other \\
Delay Preparation and approval of drawings & 0.68 & 10 & Consultant \\
Late delivery of materials and equipment & 0.68 & 11 & Resource \\
Change in the scope of the project & 0.67 & 12 & Owner \\
Incomplete design at the time of tender & 0.67 & 13 & Consultant \\
Inadequate planning and scheduling & 0.67 & 14 & Contractor \\
Fluctuation of prices of materials & 0.67 & 15 & Resource \\
labor productivity & 0.67 & 16 & Resource \\
Effect of weather & 0.67 & 17 & Other \\
Delays in decisions making & 0.66 & 18 & Owner \\
Mistakes during construction & 0.65 & 19 & Contractor \\
Poor project management & 0.65 & 20 & Consultant \\
Lack of experience & 0.65 & 21 & Contractor \\
Lack of coordination between parties & 0.64 & 22 & Other \\
Lack of communication between parties & 0.64 & 23 & Other \\
Mistakes and Errors in design & 0.63 & 24 & Consultant \\
Insufficient Numbers of equipment & 0.63 & 25 & Resource \\
Unrealistic contract duration and requirements imposed & 0.62 & 26 & Owner \\
Owner interference & 0.61 & 27 & Owner \\
Laws and Regulatory Framework & 0.59 & 28 & Other \\
Delay in inspection and approval of completed works & 0.59 & 29 & Consultant \\
Accidents on site & 0.53 & 30 & Other \\
\hline
\end{tabular}

From Table 9, top five significant factors that contribute to the construction time overrun are cash flow and financial difficulties faced by contractors ( $\mathrm{RII}=0.73$ ), poor site management and supervision (RII $=0.71$ ), incompetent subcontractor $(\mathrm{RII}=0.71)$, shortage of site workers $(\mathrm{RII}=0.71)$ and financial difficulties of owner $(\mathrm{RII}=0.71)$. From the top five factors, three factors are from contractor responsibility category, one from resource related factors category and one from owner responsibility category. It shows that, most of the factors causing 
construction time overrun are related to contractor responsibility. Of thirty factors listed, law and regulatory framework from OTH06 category, delay in inspection and approval of completed works from COS01 category and accidents on site from OTH03 category, have the lowest ranks

As seen, cash flow and financial difficulties faced by contractors is placed at first rank which belong contractor related factors. This finding is in coinciding with the findings other research works such as Mahamid (2011) mentioned that the financial status of a contractor is one of risk factors to time overrun which need to be controlled and reduced. Alaghbari et al. (2007) also found financial problems by contractor as the most significant factor in causing time overrun and second rank in top ten ranking which show that this is very important factor that should be given a serious attention. Second ranked factor for affecting time overrun is poor site management and supervision which is also from contractor responsibility category. Le-Hoai et al. (2008) found that this factor is the most important factor is Vietnamese construction industry. In a study of construction delay causes in Malaysia, Sambasivan and Soon (2007) listed this factor at the second rank. They stated that the contractor's poor site management is one of the most significant causes in causing the construction time overrun. It is caused by various issues that arise at the site and exerts a negative impact on the overall work progress.

Incompetent subcontractor is placed at third places. Typically in large projects, there are many subcontractors working under main contractor, and if the subcontractor is capable, the project can be completed on time as planned. However if the subcontractor under performs, the project can be behind the schedule because of inadequate experience or capability of the worker (Sambasivan \& Soon 2007, Abedi et al. 2011a). Shortage of workers from resource related factors category is fourth ranked factor in the overall ranking. Mahamid (2011) mentioned that insufficient labors are moderately importance to the problem of time over run, but it needs to be controlled, reduced and need to take the precautionary measures in case the problem is prolonged.

Financial difficulties by owner were placed at fifth place in the overall ranking of the factors. This factor was ranked at second place for importance ranking by Wei (2010) in his study. From Le-Hoai et al. (2008), this factor was in third place for importance ranking. The author highlighted that financial difficulties are popular in developing country. In Alaghbari et al. (2007) study, owner's financial difficulties are the major factors causing the schedule delay.

\section{Summary}

This study investigated the time overrun factors in construction industry of central and southern parts of Malaysia. It involved survey with questionnaire form consisting of 30 common factors of time overrun. A total of 75 completed questionnaire sets were analyzed and found that the significant factors contributing to construction time overrun are cash flow and financial difficulties faced by contractor, poor site management and supervision, incompetent subcontractor, shortage of workers and financial difficulties of the owner. It is recommended that proper planning of work, committed leadership and management, and effective communication system can be very helpful in improving time performance.

\section{Acknowledgements}

The authors would like to thank Universiti Tun Hussein Onn Malaysia for supporting this study under FRGS1221. Also, we are thankful to construction practitioners for providing comprehensive and important information, and a lot of cooperation which made data collection easier. Aftab Hameed Memon is also thankful to Quaid-e-Awam University of Engineering, Sciences and Technology for granting permission to carry out research work at Universiti Tun Hussein Onn Malaysian.

\section{References}

Abedi, M., Fathi, M. S., \& Mohammad, M. F. (2011a). Major Causes of Construction Delays Under Client Category and Contractor Category. The First Iranian Students Scientific Conference in Malaysia, 9 \& 10 Apr 2011, UPM, Malaysia.

Abedi, M., Fathi, M. S., \& Mohammad, M. F. (2011b). Major Mitigation Measures for Delays in Construction Projects. The First Iranian Students Scientific Conference in Malaysia, 9 \& 10 Apr 2011, UPM, Malaysia.

Alaghbari. W., Kadir, M. R. A., Salim, A., \& Ernawati (2007). The significant factors causing delay of building construction projects in Malaysia. Engineering, Construction and Architectural Management, 14(2), 192-206. http://dx.doi.org/10.1108/09699980710731308

Doloi, H., Sawhney, A., Iyer, K. C., \& Rentala, S. (2012). Analysing Factors Affecting Delays in Indian Construction Projects. International Journal of Project Management, 30, 479-489. http://dx.doi.org/10.1016/j.ijproman.2011.10.004

Embong, S. (2011). Faktor-faktor Kritikal yang Mempengaruhi Tempoh Penyiapan Projek-projek Jabatan Kerja 
Raya. Master Thesis, Unpublished, Universiti Teknologi Malaysia.

Enshassi, A., Al-Najjar, J., \& Kumaraswamy, M. (2009). Delays and Cost Overruns in the Construction Projects in the Gaza Strip. Journal of Financial Management of Property and Construction, 14(2), 126-151. http://dx.doi.org/10.1108/13664380910977592

Fugar, F. D. K., \& Agyakwah-Baah, A. B. (2010). Delays in Building Construction Projects in Ghana. Australasian Journal of Construction Economics and Building, 10(1/2), 103-116.

Hamzah, N., Khoiry, M. A., Arshada I., Tawil, N. M., \& Che Ani, A. I. (2011). Cause of Construction Delay Theoretical Framework. 2nd International Building Control Conference 2011, Procedia Engineering, 20, 490-495.

Ibrahim, A. R., Roy, M. H., Ahmed, Z., \& Imtiaz, G. (2010). An Investigation of the Status of the Malaysian Construction Industry. Benchmarking: An International Journal, 17(2), 294-308. http://dx.doi.org/10.1108/14635771011036357

Le-Hoai, L., Lee, Y. D., \& Lee, J. Y. (2008). Delay and cost overruns in vietnam large construction projects: A comparison with other selected countries. KSCE Journal of Civil Engineering, 12(6), 367-377. http://dx.doi.org/10.1007/s12205-008-0367-7

Mahamid, I. (2011). Risk matrix for factors affecting time delay in road construction projects: Owners' perspective. Engineering, Construction and Architectural Management, 18(6), 609-617. http://dx.doi.org/10.1108/09699981111180917

Memon, A. H., \& Rahman, I. A. (2013). Analysis of Cost Overrun Factors for Small Scale Construction Projects in Malaysia Using PLS-SEM Method. Modern Applied Science, 7(8), 78-87. http://dx.doi.org/10.5539/mas.v7n8p78

Memon, A. H., Rahman, I. A., \& Azis, A. A. A. (2012). Study of Causative Factors of Cost Overrun in Large Projects of Southern Part of Peninsular Malaysia. International Journal of Real Estate Studies (INTRESTS), 7(2), 1-15.

Memon, A. H., Rahman, I. A., Abdullah, M. R., \& Azis, A. A. A. (2011). Time Overrun in Construction Projects from the Perspective of Project Management Consultant (PMC). Journal of Surveying, Construction and Property, 2(1), 54-66.

Memon, A. H., Rahman, I. A., Aziz, A. A. A., Ravish, V. K., \& Hanas N. I. M. (2011b). Identifying Construction Resource Factors Affecting Construction Cost: Case of Johor. Malaysia Technical Universities International Conference on Engineering \& Technology (MUiCET 2011).

Rahman, A. H., Wang, C., Takim, R., \& Wong, S. M. (2011). Project Schedule Influenced by Financial Issues: Evidence in Construction Industry. Scientific Research and Essays, 6(1), 205-212.

Ramanathan, C. T., Potty, N. S., \& Idrus, A. B. (2011). Risk Factors Influencing Time and Cost Overrun In Multiple D\&B Projects In Malaysia: A Case Study. Proceedings of the 2011 IEEE IEEM, pp. 854-859.

Ribeiro, F. L. (1999). Construction Management of Large Scale Building Project. The Case of Colombo Centre Project, Lisbon, Portugal. CIB, E \& FN Spon, London and New York.

Sambasivan, M., \& Soon, Y. W. (2007). Causes and Effects of Delays in Malaysian Construction Industry. $\begin{array}{llll}\text { International Journal of Project } & \text { Management, }\end{array}$ http://dx.doi.org/10.1016/j.ijproman.2006.11.007

Wei, K. S. (2010). Causes, Effects and Methods of Minimizing Delay in Construction Project. Unpublished Bachelor Degree Project Thesis, Universiti Teknologi Malaysia

William, T. (2010). Construction Management: Emerging Trends and Technologies. Delmar Cengage Learning, United States of America, pp. 2 \& 112.

Yang, J., \& Wei, P. (2010). Causes of Delay in the Planning and Design Phases for Construction Projects. Journal of Architectural Engineering, 16(2), 80-83. http://dx.doi.org/10.1061/ (ASCE)1076-0431(2010)16:2(80)

\section{Copyrights}

Copyright for this article is retained by the author(s), with first publication rights granted to the journal.

This is an open-access article distributed under the terms and conditions of the Creative Commons Attribution license (http://creativecommons.org/licenses/by/3.0/). 